\title{
Prevalence and Causes of Visual Impairment in Ekiti, Nigeria: A Hospital Based Study
}

\author{
Ajayi I*, Omotoye $0 \mathrm{~J}$, Ajite K and Omotoso Olagoke 0 \\ Department of Ophthalmology, Faculty of Clinical Sciences, Ekiti State University Ado- \\ Ekiti, Nigeria
}

*Corresponding author: Ajayi Iyiade, Department of Ophthalmology, Faculty of Clinical

\section{Research Article \\ Volume 3 Issue 4}

Received Date: May 30, 2018

Published Date: June 18, 2018

Sciences, Ekiti State University Ado-Ekiti, Nigeria, Tel: +2348034311540; Email: iyiseye2005@gmail.com

\section{Abstract}

Introduction: Visual impairment is a global burden. The negative impact extends from the immediate family to the society at large. The causes vary with geographic, ethnic and cultural influences. Most data used for planning eye care services are generated either from urban areas where the large eye hospitals are situated or from small focal surveys. Effective use of existing resources is mandatory in targeting the avoidable causes of blindness in order to achieve the goals of Vision 2020.

Objectives: This study was conducted to determine the prevalence, demographic profiles and causes of visual impairment in a tertiary eye care facility in a semi urban southwestern state of Nigeria

Methodology: A descriptive study was carried out to determine the causes of visual impairment seen over a period of 1year (January-December 2016). Records of all new cases with visual acuity below 6/18 in one or both eyes were studied. Demographic characteristics, level and causes of visual impairment were extracted and entered into Statistical Package for Social Sciences (SPSS version 20.0). Data were analysed and assessed for frequency, distribution and comparison of categorical data with statistical significance inferred at $\mathrm{P}<0.05$.

Results: Visual impairment constituted $445(33.97 \%)$ of the total number of new patients seen. The ages ranged from 2years to 105 years with a mean age of 53.6years \pm 23 .6years.More females were seen with a Male: Female ratio of 1:1.1. Blindness constituted $42.9 \%$ of cases of blind eyes at presentation. Bilateral blindness occurred in 100 patients (22.5\%) of cases. There was an observed greater risk of visual impairment among patients with unilateral eye disorders (3.758(95\% CI 3.075-4.594) chi square <0.001). The major causes of visual impairment were Cataract (29.7\%), Glaucoma (!7.8\%), Refractive error(11.2\%), Retinal disorders(13.2\%) and corneal disorders(10.8\%).

Conclusion: Consistently good optical and cataract surgical services will go a long way to reduce the burden of visual impairment in Ekiti. There is also a need for improved retinal service delivery as retinal disorders have been found to be on the increase as a cause of visual impairment. Low vision services should be made available for patients.

Keywords: Blindness; Visual impairment; Low vision; Refractive error 


\section{Open Access Journal of Ophthalmology}

Abbreviations: PVA: Presenting Visual Acuity; BCVA: Best Corrected Visual Acuity; SPSS: Statistical Package for Social Sciences.

\section{Introduction}

Visual impairment is strongly associated with reduced quality of life $[1,2]$. It could affect work, study and social activities in adults and children [3]. The developing world harbours almost $90 \%$ of the world's blind [4]. In Nigeria $63 \%$ of the population lives in the rural areas with limited access to eye care services [5]. Until 2007, Nigeria had no accurate population data to plan and evaluate eye care services [5]. Existing resources must be effectively utilized to target the major avoidable causes of blindness [6]. The result of this study will provide the required knowledge of prevalence and causes of blindness and low vision.

\section{Methodology}

Our University Teaching Hospital is a semi urban tertiary health care Centre that provide Ophthalmological services among other specialized health care services . It is located in the state capital which is accessible to all the 16 local governments in the state with a population of $2,384,212$ as well as to the localities around its borders in the neighbouring states like Ondo, Kogi, Kwara and Osun . The well developed subspecialty services makes the Centre to be sufficiently equipped to offer specialized services to referred patients from within and outside the state. Records of all new patients who presented with V/A of $<6 / 18$ in either or both eyes from January to December 2016 were retrieved. Data obtained include Demographic parameters, place of residence, social habits, presenting visual acuity (PVA), best corrected visual acuity (BCVA) and diagnosis. Existing systemic co morbidities were also noted. Ethical approval was obtained from the institutional ethics and research committee. The study adhered to the tenets of the declaration of Helsinki. Ethical approval was obtained from the institutional ethics and research committee. Patient's confidentiality was ensured by desisting from mentioning participants' names, initials or hospital numbers. Data were entered into Statistical Package for Social Sciences (SPSS) version 20.0 and analysed.

\section{Definition of Terminologies}

Visual impairment: Presenting visual acuity (PVA) less than $6 / 18(20 / 60,0.3)$ in the better eye with best correction [7].

Blindness: Presenting visual acuity (PVA) less than 3/60 in the better eye or visual field less than $10^{\circ}$ from fixation.
The cause of vision loss was determined based on the principles outlined in the WHO Prevention of Blindness Proforma (version III) World Health Organization. Coding Instructions for the WHO/PBL Eye Examination Record (version III) PBL/88.1.1998;WHO Geneva) [8].

\section{Results}

A total of 445 cases of visual impairment presented during the period of study thus constituting $33.97 \%$ of the total of 1310 new patients seen. The ages ranged from 2 years to 105 years with a mean of 53 .6years \pm 23 .6years and median of 60.0years. Males were 219(49.2\%) while females constituted $50.8 \%$ of the total number of cases. There were 93(20.9\%) singles, 302(67.9\%) married and $50(11.2 \%)$ widowed/divorced. Skilled workers accounted for $200(44.9 \%)$ while $245(55.1 \%)$ were unskilled workers. About 205(46.1\%) resided within the state capital while the remaining $240(53.9 \%)$ resided outside the state capital. There was no statistically significant difference in the number of patients presenting from within and outside the state capital $(\mathrm{P}=0.12)$ History of alcohol intake was positive in $131(29.4 \%)$ of the cases while $37(8.3 \%)$ had history of cigarette smoking. Hypertension was a coexisting systemic disorder in $70(16.8 \%)$ and diabetes mellitus in $22(5.3 \%)$.

\begin{tabular}{|c|c|c|c|}
\hline Age & Males & Females & Total \\
\hline s16years & 16 & 30 & $46(10.3 \%)$ \\
\hline >years & 203 & 196 & $399(89.7 \%$ \\
\hline
\end{tabular}

Table 1: Age-Sex distribution.

There were more females among those aged less than 16years giving a risk ratio of 1.328 (CI 1.051-1.677) Chi square 0.043 (Table 1 ).

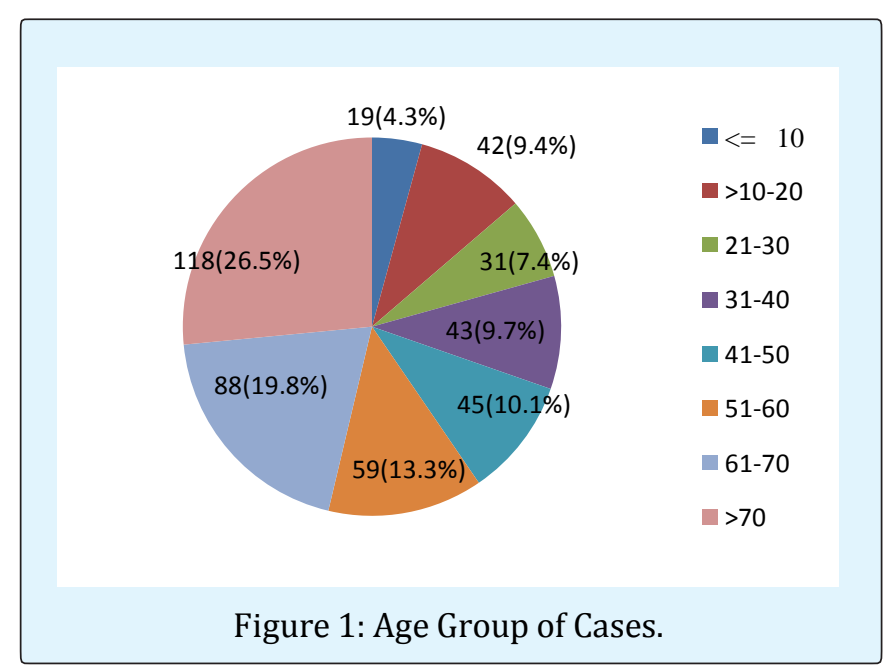




\section{Open Access Journal of Ophthalmology}

The proportion of patients increased from age 40years upward with highest number above 70years of age (Figure 1). The prevalence of blindness was $66.5 \%$ while $33.5 \%$ of the patients had low vision. Out of those with blindness, 196(44\%) and 100(22.5\%) had unilateral and bilateral blindness respectively. Of those patients with low vision, 37 (8.3\%) presented with unilateral low vision while $112(25.2 \%)$ presented with bilateral low vision.

The risk of blindness was also found to be higher among subjects with unilateral eye disorders. $\mathrm{RR}=2.234(95 \%$ CI $1.894=2.636)$ chi square $<0.001$.

\begin{tabular}{|c|c|c|}
\hline Visual Acuity & $\begin{array}{c}\text { At } \\
\text { Presentation }\end{array}$ & $\begin{array}{c}\text { Best } \\
\text { Corrected }\end{array}$ \\
\hline$\geq 6 / 18$ (Normal) & $222(24.9 \%)$ & $317(35.6 \%)$ \\
\hline Mild visual impairment & $247(27.7 \%)$ & $184(20.7 \%)$ \\
\hline $\begin{array}{c}\text { Moderate visual } \\
\text { impairment }\end{array}$ & $39(4.4 \%)$ & $28(3.1 \%)$ \\
\hline$<3 / 60$ (Blindness) & $382(42.9 \%)$ & $361(40.6 \%)$ \\
\hline
\end{tabular}

Table 2: Category of vision expressed in eyes.

There were 668 eyes (75.1\%) with varying degrees of visual impairment at presentation (Table 2). This reduced to 573 eyes $(64.4 \%)$ after best optical correction. Mild visual impairment accounted for $247(27.7 \%)$ while presenting visual acuity in the blindness category accounted for 382(42.9\%).Unskilled workers were observed to have a greater risk of visual impairment (RR:1.724 CI 1.028-2.892 P=0.025).

\begin{tabular}{|c|c|c|c|}
\hline $\begin{array}{c}\text { Laterality of } \\
\text { eye disease }\end{array}$ & $\begin{array}{c}\text { Unilateral visual } \\
\text { impairment }\end{array}$ & $\begin{array}{c}\text { Bilateral visual } \\
\text { impairment }\end{array}$ & Total \\
\hline Unilateral & 161 & 5 & 166 \\
\hline Bilateral & 72 & 207 & 279 \\
\hline Total & 233 & 212 & 445 \\
\hline
\end{tabular}

Table 3: Laterality of eye disease versus laterality of visual impairment.

Table 3 shows that $279(62.7 \%)$ had bilateral eye disorders. The odd of developing visual impairment following unilateral eye disorders was $3.758(95 \%$ CI $3.075-4.594$ ) chi square $<0.001$.

\begin{tabular}{|c|c|c|c|}
\hline Types of eye disorders & $\begin{array}{c}\text { Low } \\
\text { vision } \\
\text { no(\%) }\end{array}$ & $\begin{array}{c}\text { Blindness } \\
\text { no(\%) }\end{array}$ & $\begin{array}{c}\text { Total } \\
\text { no(\%) }\end{array}$ \\
\hline Cataract & $31(7.0)$ & $102(22.9)$ & $133(29.9)$ \\
\hline Primary Glaucomas & $19(4.3)$ & $60(13.5)$ & $79(17.8)$ \\
\hline Refractive eror & $41(9.2)$ & $9(2.0)$ & $50(11.2)$ \\
\hline Corneal disorders & $14(3.2 \%$ & $34(7.6)$ & $48(10.8)$ \\
\hline Macular diseases & $13(2.9)$ & $20(4.5 \%)$ & $33(7.4)$ \\
\hline Uveitis & $9(2.0)$ & $16(3.6)$ & $25(5.6)$ \\
\hline Optic nerve disorders & $4(0.9)$ & $17(3.8)$ & $21(4.7)$ \\
\hline Traumatic eye injuries & $7(1.5)$ & $7(1.5)$ & $14(3.1)$ \\
\hline Retinal detachment & 0 & $9(2.0)$ & $9(2.0)$ \\
\hline $\begin{array}{c}\text { Hypertensive/Diabetic/Sic } \\
\text { kle cell retinopathies }\end{array}$ & $5(1.1)$ & $3(0.7)$ & $8(1.8)$ \\
\hline Neovascular Glaucoma & 0 & $6(1.3)$ & $6(1.3)$ \\
\hline \begin{tabular}{c} 
Retinitis Pigmentosa \\
\hline $\begin{array}{c}\text { Other lens related } \\
\text { disorders }\end{array}$
\end{tabular} & $1(0.2)$ & $5(1.1)$ & $6(1.3)$ \\
\hline $\begin{array}{c}\text { Central Retinal vein } \\
\text { occlusion }\end{array}$ & $2(0.4)$ & $1(0.2)$ & $3(0.7)$ \\
\hline Eyelid disorders & 0 & $2(0.4)$ & $2(0.4)$ \\
\hline Cranial nerve 3 palsy & $2(0.4)$ & 0 & $2(0.4 \%)$ \\
\hline
\end{tabular}

Table 4: Eye disorders among patients.

Cataract was the leading cause of visual impairment accounting for $29.9 \%$ of all followed by primary glaucomas (17.8\%), (Table 4) Retinal disorders (13.8\%), Refractive error $(11.2 \%)$, Corneal disorders $(10.8 \%)$ and macular diseases $(7.4 \%)$

\section{Discussion}

Out of a total of 1310 new patients seen during the period of study, 445 cases presented with varying forms of visual impairment. This gives a prevalence of $33.97 \%$. Bilateral blindness accounted for $13.6 \%$ while unilateral blindness accounted for 9.0\%. Unilateral low vision accounted for $3.7 \%$ while bilateral low vision accounted for $7.7 \%$. These rates are higher than the rates reported in the South-Eastern part of the nation with 6\% uniocular blindness and 3.9\% binocular blindness [9]. 


\section{Open Access Journal of Ophthalmology}

A lower blindness rate of $8.4 \%$ and higher (59.4\%) low vision rate were reported in Abeokuta in Ogun State [10]. Visual impairment have been observed to constitute a high proportion of eye care service use in various studies $[11,12]$ and results in important reduction in functional status [13].

Children below 16 years of age constituted $10.3 \%$ of total cases of visual impairment (Table 1). Childhood blindness constitutes $3 \%$ of world's blind population with at least $80 \%$ of the world's visually impaired children living in low and middle income countries where such children are predisposed to a lifetime of poverty and illiteracy [14]. The number of visually impaired patients increased with age from 40years (Figure 1) with the highest number among those aged 70 years and above. This agrees with findings from other studies where risk of visual impairment has been observed to increase with age because of the increased risk of occurrence of visually disabling diseases with increasing age [15-18]. This could also serve as an explanation for the observed $22.2 \%$ of systemic co morbidities like diabetes mellitus and hypertension among the cases as these are majorly age related systemic disorders.

A higher number of females were observed in this study. This was statistically significant (chi sq 0.043 ) in the age group less than or equal to 16years. Increasing evidences show that women are affected by blindness and visual impairment to a much greater degree than men $[19,20]$. Some of the reasons for this are that the feminine gender is a significant risk factor for some eye diseases with increased exposure of women to greater risk of eye diseases due to social and cultural differences between men and women, hormonal predisposition of women to some potentially blinding eye disorders [21]. Other reasons include reduced access of women to eye care and longer life expectancy of women thus exposing them to some eye diseases which occur later in life $[19,22,23]$.

There were a greater number of unskilled workers constituting $55.1 \%$ of all cases of visual impairment .Also worthy of note was the statistically significant greater odd of visual impairment among unskilled workers (RR: 1.724 CI 1.028-2.892 P0.025). This could be due to the greater eye care seeking behavior among people with formal education which would have caused them to seek eye care before significant impairment of vision. It has also been suggested that greater knowledge, higher social class and greater financial prowess may make the skilled workers seek eye care before significant visual impairment results [8].
About half of the patients resided outside the state capital. It can therefore be averred that the eyecare service centre provides care for people residing outside its location and it could also imply that our eye care centre is accessible to all within and outside the state capital. There was no statistically significant difference between patients presenting from within and outside the state capital.

There was a $10.7 \%$ reduction in the number of visually impaired eyes with best optical correction with a reduction from $75.1 \%$ to $64.4 \%$. The impact of the optical correction was more pronounced among patients with presenting visual acuity in the category with mild visual impairment with a $7 \%$ reduction in the number in that category (Table 2).

Cataract was the leading cause of visual impairment accounting for $29.9 \%$ (Table 4). It has been observed that although cataract is relatively easily, safely and cost efficiently treatable and in spite of the increasing rates of cataract surgery, cataract is still the leading cause of blindness and visual impairment worldwide especially in developing countries [24-26]. Various studies in Nigeria show that cataract is the leading cause of visual impairment in various parts of the nation $[10,11,15,16]$. The great backlog of cataract in Nigeria has been attributed to the increasing adult population with inadequate and inefficient control programmes and high cost of surgery in the country $[14,27]$.

Glaucoma was the second leading cause of visual impairment accounting for $17.8 \%$. It is the second cause of blindness worldwide [24]. Glaucoma is responsible for $16 \%$ of blindness in Nigerian adults and the foremost cause of irreversible blindness among Nigerian adults [28]. Most patients with glaucoma often present late to the hospitals [29]. Late presentation of patients with glaucoma has been identified as possible risk factor contributing to development of severe visual impairment and blindness [30]. Early diagnosis and intervention will help to reduce the needless avoidable blindness resulting from this condition.

Retinal disorders summed up accounted for $13.2 \%$ of all. This comprises macular diseases (7.4\%), Retinal detachment (2.0\%), hypertensive/ diabetic/sickle cell retinopathies $(1.8 \%)$, Retinitis pigmentosa $(1.3 \%$, CRVO $(0.7 \%)$. The increasing rate of visual impairment from retinal disorders in Nigeria is becoming worrisome [11,31-34]. Some of the reasons for this include increasing adult population leading to more cases of age related retinal diseases like macular degeneration and macular 


\section{Open Access Journal of Ophthalmology}

holes, increasing prevalence of diabetes and hypertension from lifestyle changes and improved diagnosis of retinal disorders from improved training and diagnostic facilities [31-34].

Refractive error was a common cause of visual impairment in our centre (Table 4). Uncorrected refractive errors constitute important ocular health problem across the globe [35-38]. As observed in this study this condition accounted for a large number of cases of mild-moderate visual impairment similar to the report from the National blindness survey in Nigeria [38] and there was a significant reduction with optical correction (Table 2). An improved optical service is important in every eye care service to reduce the burden of visual impairment from this condition.

Corneal disorders account for $10.8 \%$ of causes of visual impairment. This rate is higher than rates from other reports within our country. Majority of these were infectious and inflammatory conditions which could have become a common problem in Ekiti because many of our patients were unskilled workers like artisans and farmers with increased predisposition to corneal injuries from occupational risks and organic matters [11,39]. Avoidable causes constituted majority of the causes of visual impairment in this study. No age group was spared even though there was an increasing occurrence with increasing age with females and unskilled workers more affected. This agrees with the national report of avoidable causes accounting for $84 \%$ of blindness in Nigeria [38]. We recommend an improved optical service, subsidized cost of cataract surgeries as well as increased health education to enable early diagnosis of glaucoma and retinal disorders employed to reduce the burden of avoidable blindness in Ekiti.

\section{References}

1. Adigun K, Oluleye TS, Ladipo MM, Olowookere SA (2014) Quality of life in patients with visual impairment in Ibadan: a clinical study in primary care. J multidiscip Health 7: 173-178.

2. Brown JC, Goldstein JE, Chan TL, Massof R, Ramulu P (2014) Characterising functional complaints in patients seeking outpatient low vision services in the United states. Ophthalmology 121(8): 1655-1662.

3. Gao G, Ouyang C, Dai J, Xue F, Wang X, et al. (2015) Baseline traits of patients presenting at a low vision clinic in Shanghai, China. BMC Ophthalmology 15: 16.
4. World Health Organisation (2014-2019) Action plan for the prevention of Avoidable blindness and visual impairment, Geneva Switzerland World Health Organisation.

5. National and State population projections (2002) Nigerian Population census 1991 Analysis National Population commission, Abuja Nigeria VI: 23.

6. Dineen B, Gilbert CE, Rabiu M, Kyari F, Mahdi AM, et al. (2008) The Nigerian National Blindness and Visual Impairment Survey. Rationales, Objectives and Detailed Methodology. BMC Ophthalmology 8: 17.

7. World Health Organization (2010) ICD-10 International statistical classification of Diseases and Related Health problems $10^{\text {th }}$ (Rev. Edn.) Geneva 1992.

8. Coding Instructions for the WHO/PBL Eye Examination Record (version III) PBL/88.1.1998;WHO Geneva).

9. Dawodu OA, Osahon AI, Emifoniye E (2003) Prevalence and causes of blindness in Otibhor Okhae Teaching Hospital Irrua, Edo State Nigeria. Ophthalmic Epidemiol 10(5): 323-330.

10. Sijuwola 00, Fasina O (2012) Etiology of visual impairment among ophthalmic patients at Federal Medical Centre, Abeokuta, Nigeria. J West Afr Coll Surg 2(4): 38-50.

11. Omotoye OJ, Onakpoya OH,Ajayi IA,Ajayi EA, Ajite KO (2013) Bilateral Blindness: Prevalence and Their Utilization of Existing Eye Care Facilities in a Nigerian Rural Community. IOSR Journal of Dental and Medical Sciences 9(2): 54-59.

12. Ajite KO, Fadamiro CO, Ajayi IA, Omotoye OJ (2013) Utilization of Eye Care Services Among Staff of a Tertiary Hospital. Asia-Pac J Ophthalmol 2: 28-31.

13. Rahmani B, Tielsch JM, Katz J, Gottsch J, Quigley H, et al. (1996) The cause-specific prevalence of visual impairment in an urban population. The Baltimore Eye Survey. Ophthalmology 103: 1721-1726.

14. Larry Campbell, MNG Mani (2007) Providing educational services. Comm Eye Health 20(62): 2123.

15. Onakpoya $\mathrm{OH}$, Adeoye $\mathrm{AO}$, Akinsola $\mathrm{FB}$, Adegbehingbe BO (2007) Prevalence of blindness and visual impairment in Atakunmosa West Local Government 


\section{Open Access Journal of Ophthalmology}

Area of Southwestern Nigeria. Tanzania Health Res Bull 9(2): 126-131.

16. Oluleye TS, Ajaiyeoba AI, Akinwale MO, Olusanya BA (2006) Causes of blindness in Southwestern Nigeria: A general hospital clinic study. Eur J Ophthalmol 16(4): 604-607.

17. Bourne RA, Dineen B, Jadoon Z, Leas PS, Khan A, et al. (2005) The Pakistan National eye survey study group. The Pakistan National Blindness and Visual Impairment survey-Research Design, Eye examination, Methodology and Results of Pilot study. Ophthalmic Epidemiol 12(5): 321-323.

18. Kyari F, Gudlavalleti MV, Sivsubramaniam S, Gilbert CE, Abdul MM, et al. (2009) Prevalence of blindness and visual impairment in Nigeri: The National Blindness and Visual impairment study. Invest Ophthalmol Vis Sci 50(5): 2033-2039.

19. Courtright P, Lewallen S (2009) Why are we addressing gender issues in vision loss. Comm Eye health 22(70): 17-19.

20. Katibeh M, Pakravan M, Yaseri M, Mojgan Pakbin M, Solemanizad P (2015) Prevalence and causes of visual impairment and Blindness in Central Iran, The Yazd Eye study. J Ophthalmic Vis Res 10(3): 279-285.

21. Congdon NG, Taylor HR (2003) Age related cataract. In: Johnson GJ, Minassian DC, Weale RA, West SK (Eds). The epidemiology of Eye Disease. London: Arnold Publications.

22. Lewallen S, Mousa A, Basset K, Courtright P (2009) Cataract surgical coverage remains lower in females Br J Ophthalmol 93(3): 295-298.

23. Zhao J, Ellwein LB, Cui H, Ge J, Guan H, et al. (2010) Prevalence of vision impairment in older adults in rural China. The China nine-province survey. Ophthalmology 117(3): 409-416.

24. Pascolini D, Mariotti SP (2012) Global estimates of visual impairment: 2010. Br J Ophthalmol 96(5): 614618.

25. Bourne R, Stevens GA, White RA, Smith JL, Flaxman SR, et al. (2013) Causes of vision loss worldwide, 1990-2010: a systematic analysis. Lancet Global Health 1: e339-e349.

26. Ngondi J, Ole Sempele F, Onsarigo A, Matende I, Baba S, et al. (2006) Prevalence and causes of blindness and low vision in Southern Sudan. PLOS Med 3(12): e477.

27. Rabiu MM (2001) Cataract blindness and barriers to uptake of cataract surgery in a rural community of northern Nigeria. Br J Ophthalmol 85(7): 776-780.

28. Awoyesuku EA, Pedro-Egbe CN (2012) Clinical forms of glaucoma in a tertiary hospital in Nigeria. Port Harcourt Medical Journal 6: 3.

29. Enoch ME, Omoti AE, Momoh RO (2010) Glaucoma in a suburban tertiary care hospital in Nigeria. J Ophthalmic Vis Res 5(2): 87-91.

30. Congdon N, Wang F, Tielsch JM (1992) Issues in the epidemiology and population-based screening of primary angle-closure glaucoma. Surv Ophthalmol 36(6): 411-423.

31. Onakpoya OH, Olateju SO, Ajayi IA (2008) Retinal diseases in a tertiary hospital: the need for Establishment of a Vitreo-retinal care unit. J Natl Med Assoc 100(11): 1286-1289.

32. Ajayi IA, Omotoye OJ, Ajite KO, Ajogbasile OO (2016) Retinal Disorders in a Tertiary Eye Centre in Nigeria Pak J Ophthalmol 32(3): 152-158.

33. Oluleye TS (2012) Is Age-Related Macular Degeneration a problem in Ibadan Subsaharan Africa. Clin Ophthalmol 6: 561-564.

34. Eze BI, Uche TN, Shiwobi JO (2010) The Burden and Spectrum of vitreo-retinal diseases among ophthalmic patients in a resource-defficient tertiary Eye care setting in South Eastern Nigeria. Middle East Afr J Ophthalmol 17(3): 246-249.

35. Adegbehingbe BO, Adeoye AO, Onakpoya OH (2005) Refractive errors in childhood Niger. J surg Sci 15: 1925.

36. Kempen JH, Mitchell P, Lee KE, Tielsch JM, Broman AT, et al. (2004) The prevalence of refractive errors among adults in the United States, Western Europe and Australia. Arch ophthalmol 122(4): 499-505.

37. Ezelum C, Razavi H, Sivasubramaniam S, Gilbert CE, Murthy GV, et al. (2011) Refractive Error In Nigerian Adults: Prevalence, Type and Spectacle Coverage. Invest Ophthalmol Vis Sci 52(8): 5449-5456.

38. Abdull MM, Sivasubramaniam S, Murthy GV, Gilbert CE, Abubakar T, et al. (2009) Causes of Blindness and 


\section{Open Access Journal of Ophthalmology}

Visual Impairment in Nigeria: The Nigeria National Blindness and Visual Impairment Survey. Invest Ophthalmol Vis Sci 50(9): 4114-4120.
39. Azuamah YC, Amadi AN, Esenwa EC, Iloh GU (2013) Major causes of Low Vision and Blindness in Southeast Nigeria. IJHSR 3(12): 48-52. 